\title{
A NEW METHOD OF SYNTHESIZING THE AMIDE OF
}

\section{BE NZ YLOX YCARBONYLPROLYLLE U C Y L G L YCINE}

\author{
Zh. D. Bespalova, T.K. Lozhkina, \\ M. A. Samartsev, and I. M. Shchenkova
}

UDC 547.466 .1

The amide of prolylleucylglycine, a tripeptide with sequence 7-9 of the hypophyseal hormone oxytocin, is a key starting material in the synthesis of oxytocin both by the activated-ester method and by the method of fragment condensation. However, the methods that have been described [1, 2] for obtaining the corresponding protected tripeptide amide using the benzyloxycarbonyl protection of the amino group are not absolutely convenient for treating large amounts of materials. Furthermore, we have observed a poor reproducibility of the yields in the stages of obtaining the protected di- and tripeptides, which were difficult to purify $[1-3]$.

The sequence of reactions that we propose enables the intermediate peptides to be obtained with constant high yields and high purity. During the synthesis, the carboxy group of glycine is protected by the formation of the sodium salt, and benzyloxycarbonylleucine and benzyloxycarbonylproline are used in the condensation in the form of the p-nitrophenyl esters. The subsequent conversion of the carboxy group of the benzyloxycarbonyl tripeptide into an amide group is performed by the successive action of diazomethane and ethanolic ammonia. The amide group can also be introduced with the aid of ethyl chloroformate and ammonia or via the p-nitrophenyl ester of the tripeptide.

The reaction for a day at $20^{\circ} \mathrm{C}$ of $6.4 \mathrm{~g}$ of the p-nitrophenyl ester of benzyloxycarbonylleucine and $1.35 \mathrm{~g}$ of glycine in aqueous dioxane in the presence of $16.5 \mathrm{ml}$ of $1 \mathrm{~N} \mathrm{NaOH}$ followed by acidification of the reaction mixture and extraction of the precipitated oil with ethyl acetate gave $4.95 \mathrm{~g}$ (94\%) of benzyloxycarbonylleucylglycine (I) with $\mathrm{mp} 117-118^{\circ} \mathrm{C}$ (reprecipitation from ethyl acetate with hexane). According to the literature $[4], \mathrm{mp} 115^{\circ} \mathrm{C}$.

Substance (I) $(2.3 \mathrm{~g})$ was hydrogenated in aqueous ethanol in the presence of palladium on carbon, the resulting leucylglycine was dissolved in dimethylformamide, and then $1 \mathrm{ml}$ of triethylamine was added, followed by $2.96 \mathrm{~g}$ of the p-nitrophenyl ester of benzyloxycarbonylproline. After a day, the reaction mixture was washed by decantation with a mixture of ether and hexane $(1: 1)$ and was diluted with water; the oil that separated out crystallized on standing. This gave $2.14 \mathrm{~g}(74 \%)$ of benzyloxycarbonylprolylleucylglycine (II) with $\mathrm{mp} 162-163^{\circ} \mathrm{C}$. According to the literature [1], mp $163.5-164^{\circ} \mathrm{C}$.

A solution of $1.65 \mathrm{~g}$ of substance (II) in methanol was treated with an ethereal solution of diazomethane, the mixture was evaporated, and the residue was treated with a solution of ammonia in methanol. After a day, the methanol was distilled off and the residue was crystallized from a mixture of ethyl acetate and ether, giving $1.42 \mathrm{~g}(86 \%)$ of the amide of benzyloxycarbonylprolylleucylglycine (III) with $\mathrm{mp} 161-162.5^{\circ} \mathrm{C}$. According to the literature [1], mp $163-163.5^{\circ} \mathrm{C}$. The total yield of the tripeptide amide (III), calculated on the activated ester of benzyloxycarbonylleucine, was $60 \%$.

\section{LITERATURE CITED}

1. C. Ressler and V. du Vigneaud, J. Amer. Chem. Soc., 76, 3107 (1954).

2. M. Bodanszky and V. du Vigneaud, J. Amer. Chem. Soc., 81, 5688 (1959); M. Zaoral and J. Rudinger, Collection Czech Chem. Commun., 20, 1183 (1955); O. A. Kaurov, V. F. Martynov, and V. B. Morozov, Zh. Obshch. Khim., 40, $908(19 r 0)$.

4. R. Boissonnas, S.Guttmann, P.-A.Jaquenoud, and J .-P. Waller, Helv. Chim. Acta, 38,1491 (1955) .

5. M. Bergman, L. Zervas, and J. Fruton, J. Biol. Chem ., 111, 225 (1935).

Leningrad State University. Translated from Khimiya Prirodnykh Soedinenii, No. 6, p. 808, NovemberDecember, 1973. Original article submitted March 2, 1973.

(C) 1975 Plenum Publishing Corporation, 227 West 17th Street, New York, N.Y. 10011. No part of this publication may be reproduced, stored in a retrieval system, or transmitted, in any form or by any means, electronic, mechanical, photocopying, microfilming, recording or otherwise, without written permission of the publisher. A copy of this article is available from the publisher for $\$ 15.00$. 